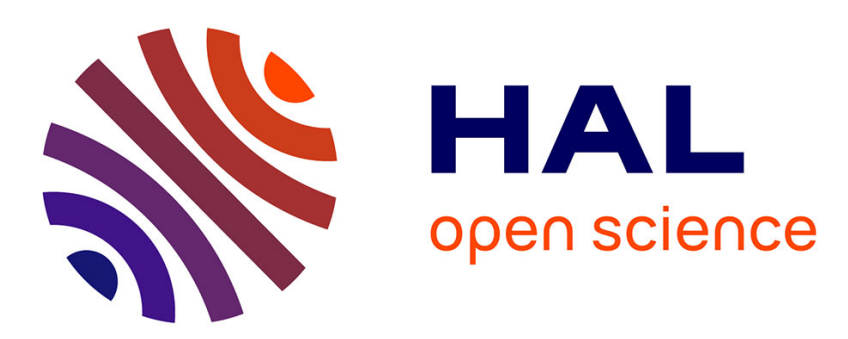

\title{
The consequences and contradictions of child and teen consumption in contemporary practice
}

\author{
Valérie-Inès de La Ville
}

\section{To cite this version:}

Valérie-Inès de La Ville. The consequences and contradictions of child and teen consumption in contemporary practice. Society and Business Review, 2007, Special Issue: Child and teen consumption, 2 (1), pp.7-14. 10.1108/17465680710725245 . hal-01845103

\section{HAL Id: hal-01845103 \\ https://hal.science/hal-01845103}

Submitted on 26 Oct 2018

HAL is a multi-disciplinary open access archive for the deposit and dissemination of scientific research documents, whether they are published or not. The documents may come from teaching and research institutions in France or abroad, or from public or private research centers.
L'archive ouverte pluridisciplinaire HAL, est destinée au dépôt et à la diffusion de documents scientifiques de niveau recherche, publiés ou non, émanant des établissements d'enseignement et de recherche français ou étrangers, des laboratoires publics ou privés. 


\author{
Society and Business Review \\ SPECIAL ISSUE ON CHILD AND TEEN CONSUMPTION 2006
}

\title{
The Consequences and Contradictions of Child and Teen Consumption in Contemporary Practice
}

\author{
Valérie-Inés de La Ville, \\ University of Poitiers, France \\ Guest Editor
}

\section{The rationale of this special issue}

Nowadays, a child is born, grows up and develops within a global consumer culture that is considered as the culture of the modern West (Slater and Tonkiss 2001). Indeed, during the second half of the twentieth century, we have changed the categories through which we talk and think of each other and of ourselves: by defining ourselves less as workers, citizens, parents or teachers, and more as consumers, we have collectively tacitly accepted that a large part of our lives is driven by consumerism (Gabriel and Lang 1995). Even though the realms of childhood and consumption have been brought together by toy manufacturers since the end of the XVIII ${ }^{\text {th }}$ century (Manson 2005), it is only in the early 1950's that marketing researchers first attempted to understand the role children play in family consumption practices (Strauss 1952). Since then, it is mainly in the fields of marketing and consumer behaviour that some crucial topics such as consumer socialisation of children, preferences formation about products and brands, assessment of the cognitive skills mastered by children to get information and make choices, and children's capacity to behave as opinion leaders or to resist to promotional techniques, have been largely explored (Gunter \& Furnham 1998 ; John 1999 ; Siegel and al. 2002 ; Young 2004 ; Tufte et al. 2005 ; Hansen \& Hansen 2005). Indeed, through everyday activities, children gradually integrate a conventional language peculiar to consumption - including concepts of brands, prices, quality, comparisons between products - and a set of social standards relating to consumption in a given cultural context - such as mastered references, search for identity, membership within a group, feeling of belonging to a social class (Oestergaard \& Jantzen 2000 ; Gronow \& Warde 2001). 
But beyond the child itself who is immersed in mundane consumption practices and permanently confronted with commercial persuasive discourses, the field of child and teen consumption can be conceptualized as a system of social practices at the cross roads of six strongly intermingled complementary subsystems (De La Ville 2005): A relational system: it covers the relationships established with all the members of the family and especially with the parents, the siblings, the grand-parents, but also with persons in charge of raising the child, the teachers, the peers... An institutional system: it includes the different institutions in charge of welcoming the child and providing him (her) with all the necessary skills to successfully integrate in a given society. As it refers to the notion of social role, this institutional dimension also contributes to define the principles for raising as well as for educating children: at school, the child increases his (her) knowledge, but he (she) also learns to behave as a pupil; within his family, the child learns to differentiate the role and responsibilities reserved for parents and those reserved for children... A plurimedia system: it encompasses all the media that the child learns to use in the course of his (her) development. If television stands out as the preferred media of young kids, the latter learn very rapidly to use computers, to read magazines, to listen to the radio, to record music, to send e-mails, to send SMS on mobiles, to surf on Internet... A narrative system: it gathers together stories, fairy tales, narrations, fiction heroes, characters, and other celebrities in real life, etc. that the child knows and recognizes. This narrative system offers concrete and symbolic markers to which the child refers when trying to explore the meaning of what he (she) lives, to express him(her)self and to exercise its judgment capacity. An economic system: it includes all the children-oriented markets, the different regulatory frames, the different actors intervening in the dynamics of new product design process, distribution, marketing communication, etc. This system includes all types of regulations and laws that facilitate or impede a strengthening of the bond between children and markets. Thus, it integrates all stakeholders including consumers' associations and even the protesters who strongly fight against the spread of capitalist ideology... A political system: As Jens Qvortrup has clearly evidenced, childhood is a social construction invested with values, hopes and even political projects (Qvortrup 1993). The social construct of childhood varies greatly according to ongoing political developments in different cultures and civilisations, resulting in quite specific ways of defining the social realms devoted to childhood in relation to adulthood in a given society (De 
Singly 2004). The most emblematic illustration of this political dimension is given by the Chinese policy of the 'single chid' launched in 1978 and recently made more flexible.

Within such a framework, child and teen consumption appears as a complex arena of competing moral and ideological perspectives. Children's and teens' consumption is shaped and transformed by a mix of managerial action, public policy, cycles of technological change, the evolution of related institutions like parenthood and schooling, changing cultural references, values, modes of socialization as well as by the actions of children and teens themselves. Thus, children-oriented commercial activities constitute a highly ambiguous and contested cultural terrain upon which many institutions and interests vie for ideological as well as economic dominance (Kline 1993 ; Kline et al. 2003 ; Cook 2004 a and b ; Schor 2004 ; Marion 2004 ; Linn 2005). In such a volatile context, forms of resistance to ideologies of unending consumption arise with intensity particularly when youth are at issue, thereby calling into question the locus of responsibility for unwanted 'effects' and the long term contribution of business itself as a social institution.

\section{The content of this special issue:}

This special issue of Society and Business Review, composed of five papers, combines empirically grounded studies as well as more theoretically-oriented discussions, with the specific intent of addressing some ethical stakes, managerial problems and profound contradictions involved with promoting child and teen consumption in Western societies. Each article sheds light at a specific level on the complexities and contradictions of marketing to children corporate, institutional, individual, professional and epistemological - offering a comprehensive picture of the operational as well as the conceptual challenges practitioners and researchers are compelled to take up.

Drawing on an extensively documented longitudinal case study on MacDonald's, Jacqueline Botterill and Stephen Kline shed light on the changes of communication strategy undertaken by this global brand over the last 40 years to meet consumer's anxieties. Corporate exploitation of its young workers, threat to specific communities' way of life, steamroller of capitalist's expansion and colonization, environmental fecklessness, and major factor in the global obesity 
pandemic that affects kids are the five main criticisms that have been addressed to McDonald's mundane managerial practices. The amazing lesson we can draw from this case study is that for many years, this arrogant corporation failed to recognize the importance of what it considered only as selective acts of defiance by isolated consumers and political activists. After loosing several trials and spending billions in public relations in vain, McDonald's was finally forced to acknowledge and meet consumers' anxieties by effectively introducing healthy changes in its menus and setting up a nutrition advisory team. The authors conclude that brand management at a global scale is not anymore just a matter of lobbying or litigating through official ways but is a much more complex task which includes perceiving and treating 'weak signals' of potentially fierce contradictions arising from several stakeholders (Ansoff 1984). But they leave open the crucial question of deciding whether McDonald's brand renewal reveals a genuine shift towards a corporate responsibility policy...

By compiling an impressive array of publications about the evolution of US school funding, Vanessa Domine evidences the continuous rise of corporate-sponsored educational materials in American schools. She highlights the moral and socio-economic implications that underlie the contradictory discourses produced about the bond between commerce and schooling. Her documented interpretation brings out four salient perspectives - celebrant, protectionist, cultural critic and educated consumer - and puts forward their respective ideological foundations and limits. These perspectives rest on contradictory assumptions about learning processes, media influence, technological innovation, children's rights, regulatory and educational public policy. The author concludes that more research is needed to achieve a deep understanding of both students' and teachers' commercially mediated experiences within schools. Considering that understanding and enriching the interpretive world of young people is the ultimate aim of the business of education, she urges for a change in the research agenda based on socioconstructivist principles. She contends that it is crucial to understand the active sense-making process about consumption that the students undertake in interaction with their teachers within classrooms. Exploring the ways in which students in interaction with a group and a teacher interpret the form and content of classroom commercial media appears to be the cornerstone of an educational policy aimed at preparing young people for participatory citizenship... 
Drawing on a fine-grained empirical work, Vebjorg Tingstad analyses teen-agers' contradictory discourses about their consumption of the popular Norvegian TV show 'Pop Idol'. On the one hand, this young audience is fascinated by the process of manufacturing an ordinary individual into a superstar through intensive and selective training. But on the other hand, these young consumers quickly question the fairness of the contest and feel deeply frustrated as they become aware that their participation in the programme through a vote system is not free. From a managerial standpoint, if it is possible to catch the attention of this young audience by enacting an innovative plot that over-emphasizes the role of hazard in the process of becoming an idol, it seems much more difficult to arouse systematic commercial responses from teenagers in order to build brand loyalty. This article is also an invitation to undertake in-depth explorations of children's and adolescents' consumption experiences, with the aim of understanding the complexities and contradictions they have to deal with to make sense of the consumption practices there are involved in.

Michelle Bergadaa's conceptual endeavour is noteworthy as it aims at differentiating the levels of social responsibility that marketing managers are accountable for. She underlines that marketers handle complex situations that intertwine conflictive moral dimensions and contradictions that remain insoluble in practice. In order to lay the foundations of a code of ethics for marketing managers, she suggests drawing on the pragmatist perspective that values ideas and actions that lead to effective changes in situated individual practice. But nevertheless, as it is the social contribution of the marketing industry as a whole that is also at stake, she wonders whether marketing managers will be able to collectively outline a professional deontology to meet the changing requirements of Western contemporary society, and particularly the fears and hopes of its youth. Such a crucial undertaking also involves marketing academics as they have to dare promote alternative visions and definitions of marketing accountability likely to reduce the contradictions between the theory of ethics-in-use by marketing managers in their daily activities and the espoused-theory stated at the level of the corporation to satisfy the main stakeholders (Argyris and Schön 1996).

In this article Daniel Thomas Cook continues his systematic and beneficial undertaking aimed at overcoming the unproductive dualisms that clutter up the debates in the emerging field of child 
consumption (Cook $2004 \mathrm{~b}$ and 2005). He shows that the figure of the 'empowered child' is a discursive construct through which marketing professionals subtly recombine novel representations of contemporary childhood with the purpose of expanding the agency and the locus of control assigned to children within commercial realms. According to him, the politics of representation that marketing professionals privilege aim at empowering the child consumer in order to persuade that treating them as a commercial target is a harmless practice. By enacting the consuming child as an active individual who is able to make choices, marketing practitioners allow children to reach specific realms from which they were previously excluded...in an adult dominated world. But beyond this liberating narrative, children actually choose and use products designed by adults. As children are compelled to follow a pregiven set of commercial alternatives established by marketing managers, they are clearly 'disempowered' by those who pretend serving them... Supreme contradiction at the very heart of any commercial practice aimed at children.

\section{Towards socially responsible marketing to children?}

The articles included in this special issue make us aware that childhood is an evolving concept depending on the way other social evolutions take place in a given society (religion, traditional family roles, public policies, educational institutions, etc.) (Qvortrup 1993; Sirota 1998 ; James and al. 1998 ; Cook 2002 ; Cross 2002). As a major consequence, the notion of social responsibility or corporate responsibility (Pesqueux \& Biefnot 2002 ; Capron \& QuairelLanoizelée 2004) towards childhood is also a constantly evolving concept which is quite difficult to grasp)...

Nevertheless, to achieve a transformational agenda towards socially responsible marketing to children, researchers ought to avoid getting caught in the trap of clearing themselves of responsibility by formulating 'double bind' injunctions addressed to practitioners such as: "Market responsibly!" As researchers and academics, we cannot escape the responsibility which is incumbent upon us to re-define the conditions under which we can contribute to develop socially responsible research and professional practice (Maignant \& Ferrello 2004). A possible route is achieving an early exposure of future marketing managers to soundly argued criticisms against a strengthening of the bond between children and markets... Another way is to enhance 
in-depth interdisciplinary research to analyze the complex stakes - developmental, social, cultural, educational, economic, political, etc.- that are played out in children's and teen's consumption practices. It implies conducting a critical evaluation of the knowledge about youth and consumption that circulates between various social groups: children and teens themselves, families, consumer groups, teachers, childhood professionals, manufacturers, consultants, social scientists and legislators. Shouldn't we collectively attempt to design a transformative research agenda to promote socially responsible research practices and ethically embedded theoretical frameworks? Among the possible topics that could orient us in such a direction, it seems possible to suggest:

- offering ethical considerations aimed at constructing criteria to assess long-term, socially responsible marketing practices;

- analyses of the rhetoric of interests, dignity, well being of children and teens as enacted by marketing and managerial discourses and practices;

- challenging fundamental concepts and assumptions widely used in economics, management and consumer studies about the "nature" of the child or teen consumer;

- discussing the opportunity, preconditions, effectiveness and / or the ideology of consumer literacy programs;

- assessing the impact of local and international regulatory agencies, governmental laws on corporate behaviour aimed at children and teens;

- assessing the incentives required to establish socially responsible commercial actions towards this specific target;

- counterbalancing the prevalence of North American or European populations in child consumption studies by researching on children's consumer practices in other cultures, within a context of endless globalization

- redefining ownership when communal ownership is a norm in specific cultures (Cram and $\mathrm{Ng} 1999$ ).

- developing inventive methodologies that consider the child not as a mere respondent, but as a co-researcher who actively participates in the interpretation of his own experiences as an apprentice consumer (Peile 2003 ; Woodhead and Faulkner, 2003 ; Greene and Hogan, 2005). 
This tentative research agenda suggests a large variety of entry points and is an invitation to deepen the indispensable dialogue - even though sometimes demanding for both sides - between marketing practitioners and social scientists aimed at defining the moving outline of corporate social responsibility in contemporary children-oriented markets.

\section{Acknowledgements}

I would like to thank Yvon Pesqueux, Denis Darpy, Christophe Benavent, Eric Godelier and the anonymous reviewers for their help in making crucial suggestions to improve the articles herein and their contribution for this his special issue.

\section{References}

Ansoff, I. (1988). The New Corporate Strategy. London: John Wiley

Argyris, C. \& Schön, A. (1996). Organizational Learning II - Theory, Method and Practice, Addison-Wesley Publishing Company.

Buckingham D. (2000). After the Death of Childhood. London: Polity Press.

Capron, M. \& Quairel-Lanoizelée, F. (2004). Mythes et réalités de l'entreprise responsable Acteurs, Enjeux, stratégies, La Découverte, coll. Entreprise et société, Paris.

Cook, D.T. (Ed.) (2002). Symbolic Childhood. New York: Peter Lang.

Cook, D.T. (2004 a). The commodification of childhood - The children's clothing industry

and the rise of the child consumer, London : Duke University Press.

Cook, D.T. (2004 b). Beyond either / or, Journal of Consumer Culture - Special issue:

Children's consumer culture, Vol. 4, N², July, pp. 147-153.

Cook, D.T. (2005). The dichotomous child in and of commercial culture, Childhood, Vol. 12, №2, May, pp. 155-159

Cram, F. \& Ng, S.H. (1999). Consumer Socialisation, Applied Psychology: An International Review, 48 (3), 297-312.

Cross, G. (2002). Valves of Desire: A Historian's Perspective on Parents, Children, and Marketing, Journal of Consumer Research, Vol.29, December, 441-447.

De La Ville, V.I. (Ed.) (2005). L'enfant consommateur - Variations interdisciplinaires sur l'enfant et le marché, (The Child Consumer - Interdisciplinary variations on the child and the market) Paris: Editions Vuibert.

De Singly, F. (Ed.) (2004). Enfants - Adultes : vers une égalité de statuts?, Encyclopedia Universalis, Paris.

Gabriel, Y. \& Lang, T. (1995). The Unmanageable Consumer: Contemporary Consumption and 
its Fragmentation. London: Sage Publications.

Greene, S. \& Hogan, D. (eds.) (2005). Researching Children Experience - Methods and Approaches, London: Sage.

Gronow, J. \& Warde, A. (2001). Ordinary Consumption. London: Routledge.

Gunter, B. \& Furnham, A. (1998). Children as Consumers. London and New York: Routledge

Hansen, F. \& Hansen, M.H. (2005). Children as innovators and opinion leaders, in Tufte, B., Rasmussen, J. \& Christensen, L.B. (Eds.). Frontrunners or Copycats?. Copenhagen DK : Copenhagen Business School Press, 38-59.

James, A., Jenks, C. \& Prout, A. (1998). Theorizing childhood. Cambridge: Polity Press

John, D.R. (1999). Consumer socialization of children: a retrospective look at twenty-five years of research », Journal of Consumer Research, $26: 3$, pp. 183-213

Kline, S. (1993). Out of the Garden: Toys and Children's Culture in the Age of TV Marketing. Toronto: Garamond Press.

Kline, S., Dyer-Witheford, N. \& De Peuter, G. (2003). Digital Play - The Interaction of Technology, Culture and Marketing, Montreal: McGill-Queen's University Press.

Linn S. (2005). Consuming kids - Protecting our children from the onslaught of marketing and advertising, New York: Anchor Books.

Manson M. (2005), Jouets du commerce et consommation enfantine dans la presse française de 1760 à 1860: de l'information au débat, in La Ville V.I.(Ed.), L'enfant consommateur, Editions Vuibert, Paris, pp.

Maignant, I. \& Ferrello, C. (2004). Corporate social responsibility and marketing: an integrative framework., Journal of the Academy of the Marketing Science, N³2, 3-19.

Marion, G. (2004). Idéologie marketing - Mal du siècle ?!, Eyrolles, Paris.

Oestergaard P. \& Jantzen C. (2000). Shifting perspectives in consumer research: from buyer behaviour to consumption studies, in Beckmann S.C. \& Elliot R. (Eds.), Interpretive Consumer Research - Paradigms, Methodologies and Applications, Denmark: Copenhagen Business School Press.

Peile L. (2003). Insight through ethnography: researching children in a different way, Journal of Advertising and Marketing to Children, October-December, 63-67.

Pesqueux, Y. \& Biefnot, Y. (2002), L'éthique des affaires - Management par les valeurs et responsabilité sociale, Editions d'Organisation, Paris.

Qvortrup, J. (Ed.) (2003). Childhood as a social phenomenon, Vienna: European Centre.

Robertson, T. S. \& Feldman, S. (1976). Children as Consumers: the need for multi-theoretical perspectives, Advances in Consumer Research, Vol. 3, Issue 1, 508-512.

Schor, J.B. (2004). Born to Buy, Scribner, New York.

Siegel, D.L., Coffey, T.J. \& Livingstone, G. (2002). The great tween buying machine Capturing your share of the multibillion dollar tween market, Chicago: Dearborn Trade Publishing 
Sirota, R. (1998). L'émergence d'une sociologie de l'enfance : évolution de l'objet, évolution du regard, Dossier Sociologie de l'enfance 1, Education et Sociétés, N², 9-33

Slater, D. \& Tonkiss, F. (2001). Market Society. Cambridge UK: Polity Press.

Strauss, A. (1952), The development and transformation of monetary meanings in the child, American Sociological Review, 17, June, 275-286

Tufte, B., Rasmussen, J. \& Christensen, L.B. (Eds.) (2005). Frontrunners or Copycats?. Copenhagen DK : Copenhagen Business School Press.

Woodhead, M. \& Faulkner, D. (2003). Subjects, Objects or Participants? Dilemmas of psychological research with children, in Christensen P. \& James A. (Eds.). Research with Children - Perspectives and Practices, London: Routledge Falmer. (First edition 2000), 9-35.

Young, B. (2004), Does advertising 